\title{
"MONASTIC" IDEA IN WINE TRADEMARKS: PECULIARITIES OF THE RUSSIAN MARKET
}

\author{
Sergey Goryaev \\ Ural Federal University, Russia \\ Olga Olshvang \\ Ural State Medical University, Russia
}

\begin{abstract}
For Russia, where grapes grow scarcely, the connection between wine and the culture of monastery life has no historical or factual basis. Moreover, during the 20th century the official ideology was atheistic, and church realities in wine names were not welcomed. Nevertheless, at the end of the 20th and the beginning of the 21st century, a large number of wine trademarks appeared in the Russian market, containing allusions to the monastic theme: Monastic Courtyard, Monk's Soul etc. Among other things, we explain this as the influence of the European and, above all, the Balkan tradition; the Bulgarian Manastiraska izba 'monastic cellar' and the Romanian Șoapta Călugărului 'monk's whisper' make up a particular model for Russian wine names.
\end{abstract}

Keywords: brand name, trade name, wine, religion.

This article deals with the names of wines in the low-price category which appeared on the Russian market in the last two and a half decades and many still present on the Russian market today. More precisely, the subject taken into consideration are trademarks of wines which include the lexemes монах 'monk' and монастырь 'monastery' along with their adjectival derivatives монашеский 'monkish' and монастьиский 'monastic'.

Theoretically, the authors want to draw attention to the intersection of the two trends typical for Russian commercial names ${ }^{1}$ that emerged in the last two and a half decades, that is, after the change in the social order that entailed a serious restructuring of the entire social life.

The first trend is the very increase in the names of such a category. The rapid

1 Apparently, this term wins in modern onomastics on the international level, as it is fixed by the publication of Sjöblom's contribution to The Oxford Handbook of Name and Naming (2016). However, in the Russian onomastic tradition, the term advertising name (Kryukova 2004) was proposed for the designation of trademarks as linguistic units, which does not always correspond to the scope of the concept, and in Eastern European tradition a broader term, chrematonym (Gałkowski 2011), is gaining strength. It will be interesting to observe the development of onomastic terminology in the field of trade names, company names etc. 
quantitative growth of commercial onomastics is due to the fact that in the changed economic conditions, in the transition from planned to competitive economy, the role of advertising and of the proper name as a part of advertising strategy are dramatically increasing. The massive emergence of such names is even estimated by researchers as a "nominative explosion"2. Nevertheless, internal language changes play an important role - in the modern mass linguistic consciousness there are ideas that a product must necessarily obtain its own name. We venture to suggest that, for languages serving economically developed nations, the obligation of commercial proper names becomes a sort of linguistic universal.

The second trend is a change in the evaluation of the religious component of everyday culture that occurred as a result of the abolition of official atheistic ideology. Consequently, words from the sphere of sacredness, which officially had a negative connotation, gained a positive connotation and even a pronounced advertising potential $^{3}$.

It should also be noted that at the turn of the 21 st century such a view resulted in a situation that can be called "the time of chaotic branding", in which there was no longstanding advertising market, serious legal regulation or development of marketing, and every business owner created trademarks. Nominative creativity in the commercial field is almost unlimited from the extralinguistic point of view: disorder, underdevelopment and practical "optionality" of the enforcement of law on trademarks meant that the nominator could not pay much attention to legislative restrictions on the creation of a wine name, for example, on the similarity of a new pragmonym with names already existing on the market. In this case, we are not talking about counterfeit products, which just falsify an existing name. It means that the release of wine for sale could not be accompanied by a test of the patent purity of the name. In addition, it is also important that manufacturers do not have funds for serious marketing research and, even with respect to the 1990s, marketing research was not fully understood. Thus, the old Soviet principles for the creation of trademarks have been lost ${ }^{4}$, and the marketing strategies developed by the Western world, including branding, are yet to appear.

This applies not only to the Russian situation, but also to the situation in

2 In particular by Romanova (2009). Although the researcher speaks about ergonyms the term used in Russian onomastics for company names -, the notion of "nominative explosion" is quite applicable to trade names.

3 The definition from the comprehensive dictionary of $1934-1940$ is characteristic in this regard: "Монах [monakh] 'Monk' (...) Member of the church community who made a vow to lead an ascetic life in the monastery according to established church rules. The hypocrisy of asceticism and the depravity of monks have been denounced by free-thinking writers of the Renaissance” (Ushakov 1934-40 v.2: 356); “Монастырь [monastyr] 'Monastery' (...) 1. Land and church organisation, which is a community of monks or nuns. Monasteries are instruments of political oppression and exploitation of the masses" (Ushakov 1934-40 v.2: 356). In the recent abridged re-edition of the dictionary, the article about 'monk' is removed and in the article for 'monastery' the attitudinal part of the definition is omitted (Ushakov 2013: 308).

4 As applied to the Soviet situation, the legal difference between varietal designations and 
neighboring countries. This article examines not only the products of Russian companies, but also the products of Ukrainian and especially Moldovan companies, which were produced for the Russian market and, accordingly, received Russian designation.

In addition, inexpensive varieties of wine differ little in terms of consumer qualities and are designed for "ordinary" people, not gourmets or specialists. In this respect, a special "competitive" load falls on the trademark; the wines receive vivid names, issued as unquestionable proper names, in quotes, with capital initials (if it concerns texts on websites, for example), graphically marked on the label. However, wines of a higher rank function only with descriptions - indications of the place of manufacture, whose name serves as a trademark. All this assumes special creative efforts of the nominator to create the name of a wine. It is also necessary to point out that trademarks for inexpensive sorts of wine are "umbrella" in nature and usually cover four positions at once: red dry, red semisweet, white dry and white semisweet.

At the same time, the abundance of names of wine, which exceeds the number of wine varieties actually marketed, is also noted by winemakers:

Many Moldovan wine trademarks have some national characteristics. One of them is a short life. Certain manufacturers produced not very high-quality wine under the new trademark. As soon as it became recognizable, the consumer stopped buying it. And the company came up with another trademark. Therefore, there was such a huge amount of TM [trademarks - our acronym]. The second feature is the similarity of names. Once some company registers the trademark and begins its promotion, the competitors attack the derivatives of its name, instead of creating something themselves. This is especially noticeable in relation to the ecclesiastical topic [our emphasis - we will return later to the "Moldovan topic"] (Taran 2006).

Thus, the variety of names of ordinary wines due to the similarity of products is the figment of the imagination and the result of the creative activity of the nominator, rather than the result of a qualitative difference between the designated wines. Without support in a variety of properties and characteristics of the object, the creator of the name "draws inspiration" not so much from the specifics of a particular wine, as from the public image of the wine and from positive public views in general, not directly related to the wine. One orientation of such positive ideas in modern society, as it has already been noted, consists of religious ideas.

Among the wine trademarks that appeared during the last two decades, the creation of at least 70 names is motivated by religious concepts and ideas. This article deals only with 35 names limited by the above-mentioned lexical criterion ${ }^{5}$.

trademarks, brands, etc. seems to be immaterial. See, for example: "Trademarks remain in the transformed form as varietal designations” (Soboleva and Superanskaya 1986: 154).

5 For this publication, a part of the material published in the Russian-language article (Goryaev 2014) was redesigned and rethought. On this occasion, the authors express their deep gratitude to their colleagues, above all to Prof. Dr. Larisa Soboleva for valuable comments. 


\section{"Monastic" wines}

In the case of wine trademarks containing the reference to monastic life, the addressee of the advertising message is not the person involved in this life but the one who is foreign to it, as the ecclesiastical rules prescribe restriction on wine drinking or complete abstinence from it, especially for monastics ${ }^{6}$. Therefore, some trademarks exploit the idea of the appearance of a monastery or parts of a monastery building about which the average native speaker has some idea. In essence, these are common lexemes with the addition of the definite marker монастььркий 'monastic':

(1) Монастырский домик 'Monastic house'

(2) Монастьиский дворик 'Monastic courtyard'

(3) Монастырский сад 'Monastic garden'

(4) Монастырскал башня 'Monastic tower'

It should be emphasized that in examples (1) and (2) nouns with a diminutive suffix are used, which is fully applicable to the designation of foodstuff in Russian ${ }^{7}$. In this respect, the idea of winemaking can be associated directly with example (3) through the idea of a garden as a place where grapes can grow and indirectly with examples (1) and (2) mentioning the possible consumption of wine. However, the type of the building mentioned in example (4), although typical of monastic architecture, has nothing to do with winemaking.

In the following examples, the use of the nominal component is more figurative than direct:

(5) Монастырский очаг 'Monastic hearth'

(6) Монастьирскал доля 'Monastic destiny'

The idea of 'hearth' in example (5) is related to the idea of wine metonymically: the hearth is the fireplace in the dining room as a place of consumption of wine. The idea of the monastery as a focus of culture is typical for the Russian language; the word oyaz 'hearth' in this context is used figuratively. As for example (6), the lexeme doлs 'destiny' in Russian rather has a negative connotation - for example, in the set phrase msжелая доля 'hard luck'. For the common noun phrase, we could also assume a "fiscal meaning" - 'the share that should be given to the monastery'. This would be relevant, for example, for the historical description of feudal relations, but not for modern realities.

6 For example, the famous spiritual author of the 19th century, Ignaty Bryanchaninov (canonized saint, highly acknowledged in the Russian Orthodox Church), points out that "a monk should not consume wine at all [...]. Any pious Christian who wishes to preserve his virginity and chastity should follow this rule. The Holy Fathers followed this rule, and if they consumed wine, it was very rare and with the greatest moderation" (Ignaty Bryanchaninov 2001, v.1: 136).

7 Diminutive suffixes for nominal vocabulary with the meaning 'food, foodstuff' are noted, for example, by Fufayeva (2016: 264). However, in the field of trade marks this phenomenon has not yet become the subject of thorough examination. 
In general, the names given above are stylistically neutral, except for a slight hint of negative connotations in the last example. The following trademark stands out against the aforementioned background:

\section{(7) Монастырскал mрапеза 'Monastic meal'}

This name carries a pronounced stylistically religious nuance of meaning. It is stressed by the Old Church Slavonic word mpaneza 'meal', characteristic of Orthodox religious discourse and semantically combined with the word монастырский 'monas-

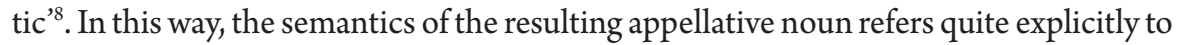
the type of the object denoted by the name - the wine is an attribute of meals.

The following example, the last one among the names built according to the grammatical model [the adjective 'monastic' + a noun], is motivated not by the lexical meaning of the components, but rather by the external phonetic form:

(8) Монастырские вечера 'Monastic evenings'

As far as one can judge, this is one of those names that appeared during the time of "chaotic branding" and it is not currently represented on the market. Thus, from the semantic point of view the name turns out to be quite random - in Russian culture there is no any particular concept of 'monastic evenings'. Nevertheless, it should be emphasized that rhythmically and alliteratively (due to the phonemes $\langle\mathrm{m}\rangle-\langle\mathrm{s}\rangle$ $<\mathrm{k}>$ and rhythm), this trade name echoes the name of the famous song Подмосковные вечера [Podmoskovnye vechera] 'Moscow nights', which has become one of the cultural symbols of Soviet Russia. Perhaps this wordplay arose in spite of the will of the nominator, as the "Soviet" topic in other names of wines is not represented".

It should be noted that the lexeme монастырь 'monastery' is itself represented only in one name from the era of "chaotic branding", but it is not used any more:

\section{(9) Горньй монастьць 'Mountain monastery'}

This phrase denotes an extremely atypical reality for Russian culture due to the peculiarities of the landscape of the habitable, central part of Russia.

8 The dictionary definition of the first meaning of the word mpaneza 'meal' in Russian is "a common table for eating food in the monastery, as well as meal (lunch, dinner) and the food itself, foodstuff" (Dictionary of the Russian language ..., 1984, v.4: 400). In the modern Church Slavonic language, the word mpaneza 'meal', except for the first meaning 'table' has very highconnoted semantics - "naming of the Most Holy Mother of God in liturgical texts" (Sedakova 2008: 360).

9 However, the "Soviet topic" in wine trademarks is indirectly manifested in the revival of a few and quite odious Soviet varieties of wine, for example, Agdam, Port 33, Port 72. In Soviet times these were cheap alcoholic beverages made of unseasoned grapes, but now they are just inexpensive table wines. 
The adjective монастырский 'monastic' is so active that it forms a number of names that do not include a noun in general:
(10) Монастырское 'Monastic'
(11) Белое монастырское 'White monastic'
(12) Красное монастырское 'Red monastic'
(13) Старомонастьиское 'Old monastic'
(14) Аревнемонастырское 'Ancient monastic'

In all these cases, the names are elliptical constructions with an implied noun 'wine' that is supported by the ending of the grammatical neuter gender in Russian, apart from the general context of the situation. Examples (13) and (14) are neologisms in the Russian language, but they have transparent internal form and are synonymous in meaning. Going beyond the scope of the article, we also note that we have knowledge of the use of these lexemes for other types of alcohol products - vodka Старомонастырскал [Staromonastyrskaya] 'Old monastic' and bitters Аревнемонастырский [Drevnemonastyrsky] 'Ancient monastic' (the word бальзам 'bitters' on the Russian market traditionally denotes alcoholic drinks, infused into herbal tea).

\section{"Monkish" wines}

As regards trademarks that include the lexeme монах 'monk', first of all we consider the names in which it is used in the nominative case and as the main word in the phrase with an adjective. These names are few:

\section{(15) Аревний монах 'Ancient monk' \\ (16) Черный монах 'Black monk' \\ (17) Бельй монах 'White monk'}

Example (15) is interesting because it updates the idea of antiquity, already presented above in the two previous "monastic" names and in example (14), using a single-root lexeme. It is necessary to recall that in mass representations the antiquity is an unconditional positive quality of wine.

The two following names form the antithesis. The emergence of the lexeme черный 'black' in example (16) can be motivated by the fact that this color is a characteristic feature of the monkish habit. In this case, example (17) should be regarded as an oxymoron, as in the Orthodox culture the secular clergy are called married clergymen in contrast to the regular clergy, the frocked monks. However, the lexeme черныц 'black' can be motivated in a different way. It is typical for the names of red wines (cf. Чернал королева 'Black queen', Черный мекарь 'Black healer', Чернал мьвииа 'Black lioness' etc.), and for the general designation of red grapes ${ }^{10}$. Thus, two examples refer to the designation of the main types of wine. In addition, for the educated person, the name

10 For the 14th-century meaning of the Russian lexeme черныц 'black', there is "an integral part of some zoological and botanical names", in particular "black grapes” (Dictionary..., V.4: 668). 
Черный монах 'Black monk' evokes an association with the story by A.P. Chekhov of the same name, but cheap table wines are designed for less educated people.

It is necessary to emphasize that, according to the available data, brand (16) belongs to Moldovan manufacturers, and one of the Russian manufacturers presented an option:

(18) Черный монах Кубани 'Black monk of the Kuban'

Thus, the very expression Черный монах 'Black monk' becomes a technical term with the meaning 'wine of a certain grade', and the component Kuban is the South Russian region which indicates the place of production. Religious semantics completely disappears.

However, the emergence of such a name may be the result of the adaptation/ borrowing ${ }^{11}$ of the relevant German brand Schwarzer Monch - in the early 2000s, some imported wines were introduced on the Russian market in both original and translated versions of the brand. The latter is convenient for "technical purposes": inscriptions in bills of lading, contracts, price tags in stores, whereas the original spelling of a foreign brand presupposes a language competence of sellers and buyers unnecessary for the situation of wine consumption. In our corpus there is an example, and we are sure about its translated nature:

\section{(19) Монах-винодел 'Monk the winemaker'}

This is an approximate translation of the German brand Wein Mönch, the only case of grammatical structure with the appositional adjunct among the trademarks in question $^{12}$, which is atypical in our view for the Russian wine market.

The lexeme монах 'monk' is included much more often in the name of a wine as a non-agreed attribute in the genitive case. One of them,

(20) Обитель монаха 'Monk’s abode',

is a paraphrase of the lexemе монастьрь 'monastery', however in a slightly higher stylistic register ${ }^{13}$.

In spite of the heterogeneity of the direct meaning of the lexemes included in them, other examples form a thematic group:

11 In the situation of "chaotic branding" - without drawing up a franchise or other legal grounds.

12 Within the framework of this article, we ignore legal issues. The subject of our consideration consists of the names under which products appear in real situations of communication, and not the strict forms of registered trademarks. Thus, the brand August Weinxof Wein Monch appears in advertising texts, catalogs, booklets in the indicated translation version.

13 Strictly speaking, the name is pleonastic, since the main meaning of 'abode' is 'monastery' (Dictionary, V. II: 534). 
(21) Ауша монаха 'Monk's soul'

(22) Сердие монаха 'Monk's heart'

(23) Тайна монаха 'Monk's mystery'

(24) Исповедь монаха 'Monk's confession'

(25) Пророчество монаха 'Monk's prophecy'

(26) Шепот монаха 'Monk's whisper'

(27) Секрет стариа 'Starets' secret'

Examples (20) and (21) are synonymous in these contexts for both Russian and English. All names are united by the semantics of mystery, religious intuitive knowledge $^{14}$ and, within the framework of Russian linguoculture, there are traditional ideas that the condition caused by the consumption of wine can bring the subject to an intuitive comprehension of the secrets of the universe.

It is also necessary to point out that example (29) is a double synonymous substitute for example (23) тайна-секрет 'mystery-secret' and монах-старец 'monkstarets. Cmapeu 'starets' is the traditional designation of a monk experienced in the spiritual life; it is characteristic that in Russian-English dictionaries for the translation of this lexeme 'monk' is given as one of the meanings. ${ }^{15}$

The following names include the lexeme монах 'monk' in the plural, which may highlight the idea of the connection between the wine and monasticism as a social group $^{16}$ :

(28) Заговор монахов 'Monks' conspiracy'

(29) Тайна монахов 'Monks' mystery'

(30) Тайный рецепт монахов 'Monks' secret recipe'

(31) Аюбимое вино монахов 'Monks' favorite wine'

As can be seen in the examples, the above-mentioned idea of mystery is actualized in these names, and if in the first two examples this idea correlates with the general religious idea of the mysterious, sacred, in example (30) it appears more "mundane", like some physical, almost material treasure. It should also be highlighted that example (29) differs from example (23) mentioned above only through the plural form, which could give rise to litigation if it were not about the situation of "chaotic branding" (in the current market the first trade name is not present).

The interpretation of example (27) requires certain background knowledge. This

14 Cf. expressed for the Russian language: "In the creation and functioning of vocabulary and phraseology with the meaning of forebodings and intuitive feelings [...], the heart and the soul are the most active" (Berezovich 2016: 181).

15 Starets - "A man, typically a monk, who is regarded as having spiritual authority, and is hence often sought out as a counsellor or guide, despite his holding no formal position in the ecclesiastical hierarchy" (https://en.oxforddictionaries.com/definition/starets).

${ }_{16}$ It is necessary to note that anti-religious propaganda in the atheistic time emphasized drunkenness as a constant quality of monks. 
trademark stands for Cahors, that is, the traditional church wine for Russia ${ }^{17}$, although this trademark has no indication of the type of wine. We also note that the trademarks of Cahors are not included in our study because the connection of this type of wine with religious culture is obvious.

As it was mentioned above, of the word-forming pair of монастырь-монастырский [monastyr-monastyrsky] 'monastery-monastic' the noun is almost not used for the trademarks of wines. With the pair монах-монашеский [monah-monashesky] 'monk-monkish', the opposite situation occurs: the adjective is rarely used because, on the one hand, the genitive form of the noun монах 'monk' is widely represented in the function of a nonagreed attribute and, on the other, the emphasis may be shifted from a person (the monk, a hypothetical wine consumer) to a religious way of life, in which the rejection of wine rather than its consumption is normative. The adjective is used only in three names:

(32) Монашескал келья 'Monkish cell'

(33) Монашеский орден 'Monkish order'

(34) Мускат монашеский 'Monkish muscat'

The name in example (32) is synonymous to a certain extent with the name given above in example (20) and is also semantically redundant. Example (33) is interesting because the author consciously or accidentally goes beyond the limits of Orthodox Church associations, since the order is a form of organizing monkish life in Western Christianity. Example (34) is not typical of the entire system of the names we are considering, as it includes the designation of a grape variety, and the name for a grape variety is characteristic of wines of a higher price level.

Finally, we consider a name that is not related to monasticism in semantics, but in phonetic form it is undoubtedly connected with the other names of our corpus:

(35) Шепот монарха [Shepot monarha] 'Monarch's whisper'

The phonetic and graphic structure of the name, which almost coincides with example (26), 'Monk's whisper', quite successful on the market, shows that the author of example (35) tried to "associate" with a more famous brand ${ }^{18}$.

\section{Prototypical wine names}

The abundance of "monkish" names has not gone unnoticed for the language community, which is reflected in particular in the criticism of these trademarks on Internet forums, on social networks, special websites, and has even led to the emergence of parodic texts: "I am telling this story about 'Monk's Prophecy' which 'Old

17 This is not reflected in the vocabulary definition of the lexeme Cahors, but it is characteristically viewed in the illustrative context: "It was Cahors, I tell you, and it was not Burgundy at all! Ordinary church wine. M. Gorky. Children” (Big academic dictionary..., V.7: 528).

18 The situation is not uncommon in low-civilized branding. It is enough to recall Abibas, a well-known brand for counterfeit products. 
Monk' uttered in a 'Monk's Whisper' lying on his deathbed in the 'Old-monastic' Courtyard[...]".."19

As we have already noted, monastic wine making is atypical for the culture of Russia. Therefore, "monkish" trademarks of wine are not a tradition for the Russian language to which one could have been returned after the disappearance of atheistic ideology as dominant.

Thus, we assume that the emergence of the whole array is caused by external influence, more precisely, by borrowing the semantic model of [monastery/monk $\rightarrow$ the name of a wine] from other onomastic traditions. We refer to the influence of the Balkan countries with traditionally developed winemaking, primarily Bulgaria and, to some extent, Romania.

The base for the borrowing of such nominations was the name of the wine known in Russia since the Soviet times, more precisely since the 70s, Монастырскал изба [Monastyrskaya izba] 'Monastic izba' (Bulgarian Манастирска изба [Manastirska izba], which is not significantly different, phonetically and graphically, from the Russian variant). The wine was exported in large quantities by the Bulgarian company Vinimpex, keeping the Bulgarian spelling of the brand. After the disintegration of economic ties, the wine was exported irregularly. Then, during the organization of the economic and legal life of the post-Soviet period, the emergence of new legislation concerning, among other things, brands and trademarks within the new legal framework, the brand was registered with the Russian spelling by a Russian company which owns the rights to Монастырскал изба 'Monastic izba' in Russia.

In terms of lexical compatibility, the name monastyrskaya izba, in Russian, looks unnatural. The point is in different meanings of the word $i z b a$ in Russian and Bulgarian, which is a typical "false cognate". In Bulgarian, the word has the meaning nozpe6 'cellar. Thus, the Bulgarian name literally means 'monastic cellar' and reflects the abovementioned idea of the monastery as the center of winemaking. In the Russian language, $i z b a$ means 'cottage, peasant house. Thus, the combination borrowed in an untranslated form looks, to a certain extent, like an oxymoron, because it combines lexemes related ideographically to two different spheres - religious and national. These spheres have been interpreted in the linguistic mentality as opposites during the last several centuries.

The lexeme монастырский 'monastic' in the trademark for wine is also supported by another Bulgarian name, appearing as Манастирско шушукане [Manastirsko shushukane] in the original spelling. This wine was not exported to the Soviet Union, but given that the Soviet-Bulgarian tourist links were, for various reasons, more developed than with any other country, the name was well known in Soviet times ${ }^{20}$. Currently, this Bulgarian wine is represented on the Russian market with the Russified name

\footnotetext{
19 http://www.cooking.ru/interceate_exchange/fido/fido7_ru_wine/message759930. html

20 We note with gratitude that this fact was brought to the attention of the authors by Yu.V. Alabugina, now the Head of the Theology Department of USPPU.
} 
Монастырское шуиуканье [Monastyrskoe shushukanie] 'Monastic whisper'. The genetic, cultural and graphic proximity of Russian and Bulgarian languages allowed the Russian native speaker to interpret the name without translation and, unlike in the case of the name Манастирска изба [Manastirska izba], this interpretation was not hindered by the same false cognate. However, perhaps, regardless of the desires of the creators of the Russified brand, the Russian name acquired a slightly ironic shade of meaning, as in Russian the lexeme has a colloquial stylistic nuance (Dictionary..., V. 4: 738 ), in contrast to the corresponding Bulgarian word.

In general, these two Bulgarian wines establish the key lexeme монастырский 'monastic', manifested in a number of derivatives of Russian names.

The emergence of the lexeme монах 'monk' may have occurred as a further interpretation of the "monastic" topic or as a borrowing from the Romanian tradition, with Moldovan mediation. Such names may be a kind of adaptation in the Russian language of the Romanian name Şoapta călugărului 'monk's whisper', although this name does not provide so many derivatives in Russian and is rather margina ${ }^{21}$. The connection of the Romanian name with the Bulgarian phrase monastyrskoe shushukanie 'monastic whisper' is lexically obvious, but the judgment about the ways of their interaction goes beyond the scope of this article and the competence of the authors. When borrowing the idea of "monkish" wine, Moldovan mediation is manifested in Russian primarily in the fact that a significant part of such names belongs to the Moldovan manufacturers, who used to be extremely active on the Russian market of inexpensive wine and deliberately created Russian-language trademarks for this market, relying on fashion and demand.

Thus, we see that in many cases, the "source of inspiration", more precisely, the motivation behind the creation of names of ordinary wines, is public religious ideas, primarily Christian ones.

Moreover, since it is in Christianity that wine plays an important symbolic role, the connection between the ideas of wine and religion may have a rational basis. However, it is the rational basis of the connection of these ideas that is scarcely represented in the material under consideration.

The corpus of the considered names may indicate that the religious sphere, in general, and the monkish life style, in particular, do not cause aversion in the large part of the society, and the concepts and ideas associated with them have an advertising effect. Despite the nebulosity of mass religious representations, the sacred becomes the source of associations for the profane and is interpreted in a positive way.

\section{References}

Березович, Е.А. 2016. Ауша и серАце как органы «шестого чувства» (на материале русского языка) [Berezovich, E.L. The soul and heart as organs of "the sixth sense"]. In

21 We judge on the publication which distinguishes about 40 names of wines in the Romanian material referring to religious symbols, but the name Şoapta călugărului is mentioned only once, and the most numerous group - 11 names - contains references to biblical characters, saints of the latest times, archangels (Siserman 2013: 162-163). 
Antropologiczno-jezykowe wizerunki duszy w perspektywie międzykulturowej. T. 1 Dusza w oczsch świata, E. Masłowskiej and D. Pazio-Wlazłowskiej (eds.), 179-194. Warszawa: IS PAN.

Big Academic Dictionary of the Russian Language. 2004. Moscow: Nauka.

Gałkowski, A. 2008. Chrematonimy w funkcji kulturowo-użytkowej. Onomastyczne studium porównawcze na materiale polskim, włoskim, francuskim [Cultural and practical functions of chrematonyms. A comparative onomastic study with reference to Polish, Italian and French]. Łódź.

Горяев, С.О. 2014. «Черный монах», «слеза монашки»: церковная тематика в названиях вин постсоветского времени // Questio rossica №3: 209-226 [Goryaev, S. 2014. The black monk and the nun's tear: church-related wine names in the post-soviet times. In Questio rossica 3: 209-226].

Игнатий (Брянчанинов) свт. 2011. Аскетические опыты. В 2 т. Т 1. Москва [Ignaty (Bryanchaninov), saint bishop. 2011. Ascetic essays. In 2 vol. V. 1. Moscow].

Крюкова, И.В. 2004. Рекламное имя: от изобретения Ао прецедентности. Монография. ВолгограА: Перемена [Kryukova, I.V. 2004. Advertising name: from invention to precedent. Monograph. Volgograd: Peremena].

Соболева, Т.А., Суперанская, А.В. 1986. Товарные знаки. М. Наука [Soboleva, Т.А., Superanskaya, A.V. 1986. Trademarks. Moscow: Nauka].

Седакова, О. 2008. Словарь трудных слов из богослужения. Церковнославянско-русские паронимы. М. Греко-латинский кабинет Ю.А. Шичалина. [Sedakova, О. 2008. Dictionary of difficult words from worship. Church Slavonic-Russian paronyms. M. Yu.A. Shichalin's Greec-Latin Cabinet].

Siserman, M. 2013. Nume de vinuri şi de soiuri de struguri româneşti. In Name and Naming. Proceedings of the Second International Conference on Onomastics. Onomastics in Contemporary Public Space. Baia-Mare, May 9-11, 2013, O. Felecan (ed.), 157-169. Cluj-Napoca: Mega, Argonaut.

Sjöblom, P. 2016.Commercial names. In The Oxford Handbook of Names and Naming, C. Hough (ed.), 453-464. Oxford University Press.

Словарь русского языка. 1981-1984. В 4-х тт. М. Русский язык [Dictionary of the Russian language. 1981-1984. In 4 vol. M. Russian language].

Таран, А. 2006. Как переименовать “монахов" и “монашек”? // Экономическое обозрение № 26 (666) 28 июмя 2006 [Taran, A. 2006. How to rename "monks" and "nuns"? In Ekonomicheskoe obozrenie 26 (666)]. http://logos.press.md/node/20751 (accessed September 29, 2017).

Ушаков, А.Н. реА. 1935-40. Толковый словарь русского языка в 4-х тт. М. [Ushakov D.N. (ed.). 1935-1940. Explanatory dictionary of the Russian language, in 4 vol. M.].

Ушаков, А.Н. 2013. Толковый словарь современного русского языка. М. ААелант [Ushakov D.N. 2013. Explanatory dictionary of the modern Russian language. M. Adelant].

Фуфаева, И.В. 2016. Экспансия экспрессивных Аиминутивов в русском языке // Вестник Нижегородского университета им. Н.И. Аобачевского № 3: 257-266. [Fufayeva, I.V. 2016. Expansion of expressive diminutives in the Russian language. In Vestnik of the Nizhny Novgorod University named after N.I. Lobachevsky 3: 257-266]. 